\title{
Evaluation of Serum 25 Hydroxy Vitamin D level in acute myocardial infarction patients in a tertiary care hospital
}

\author{
Debapriya Rath ${ }^{1}$, Rachita Nanda², Pramila Kumari Mishra ${ }^{3}$, Pradeep Kumar Patra ${ }^{4}$ \\ ${ }^{1}$ Assistant Professor, ${ }^{4}$ Director Professor, Department of Biochemistry, Pt. J.N.M. Medical College, Raipur, Chattisgarh, \\ ${ }^{2}$ Associate Professor, Department of Biochemistry, AlIMS, Raipur, Chattisgarh, ${ }^{3}$ Professor and Head, Department of \\ Biochemistry, S.C.B Medical College, Cuttack, Odisha, India
}

Background: Coronary artery disease is the leading cause of death worldwide with acute myocardial infarction being the most severe manifestation. Recent evidences have linked vitamin $\mathrm{D}$ in the pathogenesis of the coronary risk factors like diabetes, hypertension, obesity and smoking. Aims and Objectives: The present study was undertaken with an aim to look for the vitamin D status of the AMI patients and its relation if any with the above mentioned risk factors. Material and Methods: One hundred acute myocardial infarction patients along with one hundred age and sex matched healthy controls were included in the study and the serum $25(\mathrm{OH})$ D was estimated in both the groups. Results: Serum $25(\mathrm{OH})$ Vit D level was found to be lower in cases $(19.6 \pm 6.85 \mathrm{ng} / \mathrm{ml})$ than in controls $(27.5 \pm 6.23 \mathrm{ng} /$ $\mathrm{ml})(\mathrm{p}<0.001)$. The decreased vitamin $\mathrm{D}$ level was associated with the incidence of AMI after adjusting for other risk factors. The serum vitamin D level was significantly decreased in the patients having risk factors among the AMI group. Conclusion: The present study showed a significantly low serum vitamin D in AMI patients. Given the therapeutic safety and inexpensiveness of vitamin $D$, further studies may be undertaken to look for the effect of its supplementation on coronary artery disease.

Key words: Vitamin D, Acute myocardial infarction, Diabetes, Hypertension, Obesity

\section{INTRODUCTION}

Coronary artery disease $(\mathrm{CAD})$ is the leading cause of death in India and worldwide. ${ }^{1}$ The most severe manifestation of CAD is acute myocardial infarction (AMI) where there occurs sudden occlusion of the coronary artery due to formation of thrombus. It is multi-factorial in origin with the common risk factors being diabetes, hypertension, smoking, obesity, etc. The relationship of Vitamin D and cardiovascular disease have long been explored. Clinical studies have supported the role of Vitamin D in maintaining cardiovascular health. ${ }^{2}$ In its active form, 1,25 dihydroxy Vitamin D exerts its action through Vitamin D receptors (VDR) in various tissues, including vascular smooth muscle, endothelium and cardiomyocytes. ${ }^{3-7}$ Vit D deficiency leads to enhanced atherosclerosis secondary to vascular smooth muscle cell (VSMC) proliferation and increased production of cytokines like IL- 6 and TNF- $\alpha .{ }^{8-10}$ Recent evidences have linked Vitamin D in the pathogenesis of coronary risk factors, including hypertension, type -2 diabetes mellitus and the metabolic syndrome. ${ }^{3-6}$ Epidemiological studies, like Health Professional Study and the Framingham Offspring Study have shown low Vit D level to be independently associated with twice the risk of incident myocardial infarction. ${ }^{11,12}$ Given the adverse health implication of Vit $\mathrm{D}$ deficiency, and it being a treatable condition and the lack of studies in this part of the subcontinent, prompted us to take up this study. The objective of the current study was to evaluate the Vit D status in patients of AMI and its association with other risk factors. 


\section{MATERIALS AND METHODS}

The study was conducted in the Department of Biochemistry, SCB Medical College, Cuttack in collaboration with the Department of Cardiology after approval from the institutional ethics committee. The study was conducted over a period of 12 months from 2013 to 2014. Written informed consent was obtained from each study individual. Study population included 100 cases of AMI admitted to the department of cardiology and 100 age and sex matched healthy individuals by random sampling of the general population.

The inclusion criteria for the cases were the diagnosis of AMI on the basis of ECG and serum biochemical findings. AMI was diagnosed by the presence of either a CK-MB elevation greater than twice normal or Troponin-I elevation of $>0.1 \mathrm{mg} / \mathrm{ml}$ within 24 hours of arrival to the hospital with a clinical presentation suggestive of an AMI (e.g. prolonged ischemic signs or chest pain symptoms, at least one ECG with ST- wave elevation or ST-wave depression in 2 or more consecutive leads).

The exclusion criteria included patients taking vitamin $\mathrm{D}$ supplementation, patient having hepatic, renal or any other chronic debilitating disease.

Five $\mathrm{ml}$ of blood was collected to carry out biochemical investigations like plasma glucose, serum urea, creatinine and uric acid. Measurement of 25-OH Vit D was performed by ELISA using DLD (Diagnostika GMBH) kit. The intra-assay coefficient of variation was $5 \%$ at serum levels of $25 \mathrm{ng} / \mathrm{ml}$ and the inter assay coefficient of variation at serum levels of $16 \mathrm{ng} / \mathrm{ml}, 25 \mathrm{ng} / \mathrm{ml}$ and $52 \mathrm{mg} / \mathrm{ml}$ were $8 \%, 6 \%$ and $11 \%$ respectively. Participants were classified into clinically-relevant categories on the basis of $25(\mathrm{OH})$ Vit D levels; $\geq 30 \mathrm{ng} / \mathrm{ml}$ were classified as sufficient, levels $>15 \mathrm{ng} / \mathrm{ml}$ and $<30 \mathrm{ng} / \mathrm{ml}$ were considered insufficient, and levels $\leq 15 \mathrm{ng} / \mathrm{ml}$ deficient. ${ }^{13}$ Statistical analysis of student's $t$ test, ANOVA, correlation coefficient and regression analyses were performed using SPSS 17.

\section{RESULTS AND DISCUSSION}

With $65 \%$ of the patients being males, the mean age of patients in years was $57.1 \pm 7.55$ years with maximum number within the age group of 51-60 years. The other characteristics like BMI, blood pressure (systolic and diastolic) were elevated but not statistically significant in AMI patients. In AMI patients, diabetes was the most prevalent $(46 \%)$ risk factor followed by hypertension (39\%) and smoking $(30 \%)$. At least a single risk factors was present in $72 \%$ of patients, with $38 \%$ having more than one risk factor and 28\% having no risk factor, which indicates that the incidence of AMI was more prevalent in persons with risk factors than those having none (Table 1).

Routine biochemical tests like fasting plasma glucose, serum urea and creatinine showed no statistical significance (Table 2). The serum uric acid, elevated $(\mathrm{p}<0.05)$ in AMI patients may be an indicator of the increased xanthine oxidase activity in vivo under ischemic conditions. ${ }^{14,15}$

Serum $25(\mathrm{OH})$ Vit $\mathrm{D}$ level was found to be low in cases $(19.6 \pm 6.85 \mathrm{ng} / \mathrm{ml})$ than in controls $(27.5 \pm 6.23 \mathrm{ng} / \mathrm{ml})$ $(p<0.001)$. Since Vit D controls calcium levels and hence myocardial contractility, a deficiency in Vit D has been shown to be associated with irregular cardiac contractility, cardiomegaly and with collagen deposition in the myocardium. ${ }^{16,17}$ Also deficiency of Vit D leads to progression of atherosclerosis following vascular smooth muscle cell proliferation and excessive production of pro inflammatory cytokines like TNF- $\alpha$ and IL- $6 .{ }^{18-20}$

Multiple risk factors and the third group patients didn't have any of these four risk factors. The vitamin D level was found to be significantly different between the 3 groups (Table 3A). The post hoc multiple comparison test showed no significant difference between the groups having single or multiple risk factors but the patients having no risk factors had a significantly higher serum $25-\mathrm{OH}$ vit $\mathrm{D}$ level than the other two groups (Table 3B).

Figure 1 revealed a highly significant negative correlation between BMI and 25(OH) Vit D level $(\mathrm{r}=-0.44, \mathrm{p}<0.001)$. Suggested explanations for this phenomenon are less

\begin{tabular}{lcc} 
Table 1: Demographic characteristics of controls and cases & AMI patients $(\mathbf{n = 1 0 0})$ \\
Parameter & Control $(\mathbf{n}=\mathbf{1 0 0})$ & $57.1 \pm 7.55$ \\
Age (years) & $56.86 \pm 9.64$ & 65 \\
Sex (males\%) & 67 & $26.17 \pm 3.32$ \\
Body mass index $\left(\mathrm{kg} / \mathrm{m}^{2}\right)$ & $25.5 \pm 2.7$ & $139 \pm 18.2$ \\
Systolic blood pressure $(\mathrm{mmHg})$ & $124 \pm 21.1$ & $91 \pm 16.9$ \\
Diastolic blood pressure $(\mathrm{mm} \mathrm{Hg})$ & $82 \pm 13.7$ & $48 \%$ \\
Sedentary lifestyle $(\%)$ & $35 \%$ & \\
\hline Values given as mean \pm S.D & &
\end{tabular}


exposure to UV radiations, lower intake of Vit D and a higher distribution volume for Vit D. ${ }^{21,22}$ Also increased metabolic clearance and enhanced uptake of Vit D in adipose tissue accounts for the low level in obesity. ${ }^{23,24}$

The AMI patients were divided into 3 groups depending upon the presence or absence of risk factors namely diabetes, hypertension, BMI $>25$ and smoking. The first group had patients with only a single risk factor, the second group had patients with multiple risk factors. As the different risk factors of AMI like diabetes, hypertension, smoking and high BMI have been shown to be associated with a lower serum vitamin $\mathrm{D}$ level, in order to look for

\section{Table 2: Biochemical parameters (mean \pm SD)}

\begin{tabular}{lcc}
\hline Parameter & Cases & Controls \\
\hline FBS $(\mathrm{mg} / \mathrm{dl})$ & $90 \pm 13.73$ & $87.46 \pm 9.42$ \\
Serum urea $(\mathrm{mg} / \mathrm{dl})$ & $28.72 \pm 10.43$ & $24.80 \pm 5.83$ \\
S. creatinine $(\mathrm{mg} / \mathrm{dl})$ & $1.15 \pm 0.44$ & $0.95 \pm 0.20$ \\
Uric acid* $(\mathrm{mg} / \mathrm{dl})$ & $5.35 \pm 0.85$ & $4.8 \pm 1.06$ \\
$25(\mathrm{OH}) \mathrm{D}^{\#} \mathrm{ng} / \mathrm{ml}$ & $19.6 \pm 6.85$ & $27.5 \pm 6.23$ \\
\hline${ }^{*} \mathrm{p}<0.05,{ }^{*} \mathrm{p}<0.001$ & &
\end{tabular}

the association of the $25(\mathrm{OH}) \mathrm{D}$ level with AMI patients in comparison to the control group, two linear regression models were analyzed. In model 1 (Table 4) analysis was done with vitamin $\mathrm{D}$ as the dependant variable and the other four risk factors and the absence or presence of AMI (cases=1, control=2) as the independent variables. The regression analysis revealed that the incidence of AMI was significantly associated with lower serum vitamin D concentration after adjusting for the rest of the variables.

In regression model 2 (Table 5) the analysis was done taking presence or absence of AMI (cases $=1$, control=2) as the dependant variable and diabetes, hypertension, smoking, BMI and serum vitamin D as independent variables. Serum vitamin D level was found to be a significant predictor of the incidence of AMI after adjusting for the other risk factors.

\section{CONCLUSION}

The present study showed a decreased level of serum vitamin $\mathrm{D}$ level in patients of acute myocardial infarction.

\section{Table 3A: Comparison of serum vitamin D in AMI patients with risk factors}

\begin{tabular}{lcccc}
\hline Sub groups in the AMI patients & Number of cases & Serum 25(OH)D level $(\mathbf{n g} / \mathbf{m l})$ mean \pm S.D & F ratio & p value \\
\hline With no risk factor & 28 & $24.9 \pm 7.03$ & 16.22 & $<0.001$ \\
With single risk factor & 34 & $18.8 \pm 6.65$ & \\
With multiple risk factor & 38 & $16.4 \pm 4.61$ & \\
\hline
\end{tabular}

\begin{tabular}{|c|c|c|c|c|c|c|}
\hline \multicolumn{7}{|c|}{ Multiple comparisons } \\
\hline \multicolumn{7}{|c|}{ Tukey HSD } \\
\hline \multirow[t]{2}{*}{ (I) group } & \multirow[t]{2}{*}{ (J) group } & \multirow[t]{2}{*}{ Mean difference (I-J) } & \multirow[t]{2}{*}{ Std. error } & \multirow[t]{2}{*}{ Sig. } & \multicolumn{2}{|c|}{ 95\% confidence interval } \\
\hline & & & & & Lower bound & Upper bound \\
\hline \multirow[t]{2}{*}{ No risk factor } & Single risk factor & $6.09874^{*}$ & 1.54978 & 0.000 & 2.4099 & 9.7876 \\
\hline & Multiple risk factor & $8.49812^{*}$ & 1.51250 & 0.000 & 4.8980 & 12.0982 \\
\hline \multirow[t]{2}{*}{ Single risk factor } & No risk factor & $-6.09874^{*}$ & 1.54978 & 0.000 & -9.7876 & -2.4099 \\
\hline & Multiple risk factor & 2.39938 & 1.43360 & 0.221 & -1.0129 & 5.8117 \\
\hline \multirow[t]{2}{*}{ Multiple risk factor } & No risk factor & $-8.49812^{*}$ & 1.51250 & 0.000 & -12.0982 & -4.8980 \\
\hline & Single risk factor & -2.39938 & 1.43360 & 0.221 & -5.8117 & 1.0129 \\
\hline
\end{tabular}

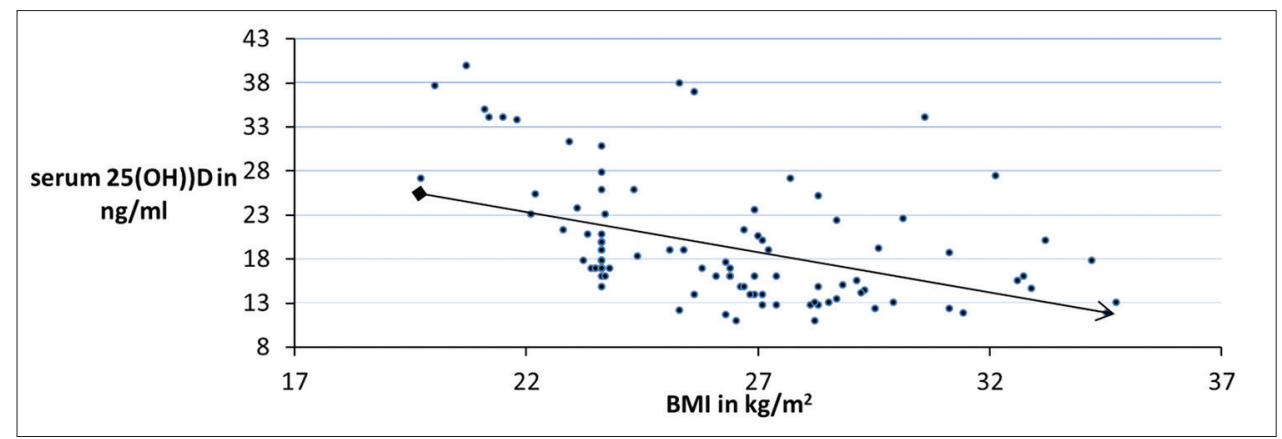

Figure 1: Correlation graph of Vit D with BMI 
Table 4: Linear regression model 1

\begin{tabular}{|c|c|c|c|c|c|}
\hline \multicolumn{6}{|c|}{ Coefficients $^{a}$} \\
\hline \multirow[t]{2}{*}{ Model B } & \multicolumn{2}{|c|}{ Unstandardized coefficients } & \multirow[t]{2}{*}{ Standardized coefficients } & \multirow[t]{2}{*}{$\mathbf{t}$} & \multirow[t]{2}{*}{ Sig. } \\
\hline & Std. error & Beta & & & \\
\hline 1 & & & & 3.698 & 0.000 \\
\hline (Constant) & 19.984 & 5.403 & 0.087 & 1.403 & 0.163 \\
\hline Smoking & 1.320 & 0.941 & 0.145 & 1.901 & 0.059 \\
\hline Diabetes & 2.110 & 1.110 & 0.097 & 1.428 & 0.156 \\
\hline Hypertension & 1.470 & 1.029 & -0.263 & -3.741 & 0.000 \\
\hline $\mathrm{BMI}$ & -0.568 & 0.152 & & & \\
\hline AMI & 6.129 & 0.994 & 0.422 & 6.167 & 0.000 \\
\hline
\end{tabular}

\section{Table 5: Linear regression model 2}

\begin{tabular}{|c|c|c|c|c|c|}
\hline \multicolumn{6}{|c|}{ Coefficients $^{a}$} \\
\hline \multirow[t]{2}{*}{ Model B } & \multicolumn{2}{|c|}{ Unstandardized coefficients } & \multirow[t]{2}{*}{ Standardized coefficients } & \multirow[t]{2}{*}{$t$} & \multirow[t]{2}{*}{ Sig. } \\
\hline & Std. error & Beta & & & \\
\hline 1 & -0.899 & 0.415 & & -2.167 & 0.032 \\
\hline (Constant) & 0.107 & 0.070 & 0.103 & 1.530 & 0.128 \\
\hline Smoking & 0.182 & 0.082 & 0.182 & 2.203 & 0.029 \\
\hline Diabetes & 0.127 & 0.077 & 0.122 & 1.657 & 0.100 \\
\hline Hypertension & 0.034 & 0.006 & 0.496 & 6.167 & 0.000 \\
\hline Vitamin D & & & & & \\
\hline $\mathrm{BMI}$ & 0.030 & 0.012 & 0.205 & 2.626 & 0.010 \\
\hline
\end{tabular}

A further decrease in the vitamin D levels was noticed in patients having cardiovascular risk factors like diabetes, hypertension and smoking.

Studies with larger sample size and long term follow up studies will be able to determine whether $25-(\mathrm{OH}) \mathrm{D}$ affects long term clinical outcomes in post MI patients.

Vitamin D is an inexpensive, and a safe nutraceutical. Therefore randomized controlled trials in future can investigate whether treating vitamin $\mathrm{D}$ deficiency can improve the incidence and clinical outcomes of acute myocardial infarction.

\section{Limitations of the study}

The study was undertaken with an intent of evaluating the serum vitamin $\mathrm{D}$ status in patients suffering from acute myocardial infarction. But the type of AMI (STEMI or NSTEMI) was not considered in the study. Another major limitation of the study was that the patients were not followed up to look for the co-relation of serum vitamin $\mathrm{D}$ status the outcome and prognosis of the disease. Also the role of vitamin $\mathrm{D}$ in the etiopathogenesis of myocardial infarction cannot be depicted from the results.

\section{REFERENCES}

1. World health Organization. Factsheet No.310. The top10 causes of death. July 2013.

2. Aggarwal N, Reis JP and Michos ED. Vitamin D deficiency and its implications on cardiovascular disease. Curr Cardio Risk Rep 2010; 4:68-75

3. Holick MF. Vitamin D deficiency. N Engl J Med 2007; 357:266-281.

4. Forman JP, Bischoff-Ferrari HA, Willett WC, Stampfer MJ and Curhan GC. Vitamin D intake and risk of incident hypertension: results from three large prospective cohort studies. Hypertension 2005; 46:676-682.

5. Forman JP, Curhan GC and Taylor EN. Plasma 25-hydroxyvitamin $D$ levels and risk of incident hypertension among young women. Hypertension 2008; 52:828-832.

6. Scragg R, Sowers M and Bell C. Serum 25-hydroxyvitamin D, diabetes, and ethnicity in the Third National Health and Nutrition Examination Survey. Diabetes Care 2004; 27:2813-2818.

7. ZittermannA, Schleithoff SS and KoerferR. Putting cardiovascular disease and vitamin $\mathrm{D}$ insufficiency into perspective. $\mathrm{Br} \mathrm{J}$ Nutr 2005; 94:483-492.

8. Mitsuhashi T, Morris RC and Ives HE. 1, 25-dihydroxyvitamin D3 modulates growth of vascular smooth muscle cells. J Clin Invest 1991; 87:1889-1895.

9. Mohtai M and Yamamoto T. Smooth muscle cell proliferation in the rat coronary artery induced by vitamin $\mathrm{D}$. Atherosclerosis 1987; 63:193-202.

10. Muller K, Haahr PM, Diamant M, Rieneck K, Kharazmi A and Bendtzen K. 1,25-Dihydroxyvitamin D3 inhibits cytokine production by human blood monocytes at the post-transcriptional level. Cytokine 1992; 4:506-512.

11. Thomas MK, Lloyd-Jones DM, Thadhani RI, Shaw AC, Deraska DJ, Kitch BT, et al. Hypovitaminosis D in medical inpatients. N Engl J Med 1998; 338(12):777-783.

12. Castelli $\mathrm{A}$, Condemi $\mathrm{M}$ and Brambillasca $\mathrm{C}$. Improvement of cardiac function by allopurinol in patients undergoing cardiac surgery. J Cardiovasc Pharmacol 1995; 119-125.

13. Kogure $\mathrm{K}$, Ishizaki $\mathrm{M}$ and Nemoto $\mathrm{M}$. Evaluation of serum 
uric acid changes in different forms of hepatic vascular inflow occlusion in human liver surgeries. Life Sci 1999; 305-313.

14. Compston JE, Vedi S, Ledger JE, WebbA, Gazet JC and Pilkington TR. Vitamin D status and bone histomorphometry in gross obesity. Am J Clin Nutr 1981; 34:2359-2363.

15. Kamycheva E, Joakimsen RM and Jorde R. Intakes of calcium and vitamin $\mathrm{D}$ predict body mass index in the population of northern Norway. J Nutr 2003;133:102-106.

16. Hey H, Stokholm KH, Lund B, Lund B and Sørensen OH.Vitamin $D$ deficiency in obese patients and changes in circulating vitamin D metabolites following jejunoileal bypass. Int J Obes 1982; 6:473-479.

17. Liel Y, Enoch U, Shary J, Hollis BW and Bell NH. Low circulating vitamin D in obesity. Calsif Tissue Int 1984; 43:199-201.

18. Weishaar RE and Simpson RU. Involvement of vitamin D3 with cardiovascular function. II. Direct and indirect effects. Am J Physiol 1987; 253:E675-E683.

19. Weishaar RE, Kim SN, Saunders DE and Simpson RU.
Involvement of vitamin D3 with cardiovascular function. III. Effects on physical and morphological properties. Am J Physiol 1990; 258:E134-E142.

20. Mitsuhashi T, Morris RC and Ives HE. 1, 25-dihydroxyvitamin D3 modulates growth of vascular smooth muscle cells. J Clin Invest $1991 ; 87: 1889-1895$.

21. Mohtai $\mathrm{M}$ and Yamamoto $\mathrm{T}$. Smooth muscle cell proliferation in the rat coronary artery induced by vitamin D. Atherosclerosis 1987; 63:193-202.

22. Muller K, Haahr PM, Diamant M, Rieneck K, Kharazmi $A$ and Bendtzen K. 1,25-Dihydroxyvitamin D3 inhibits cytokine production by human blood monocytes at the post-transcriptional level. Cytokine 1992; 4:506-512.

23. Giovannucci E, Liu Y, Hollis BW and Rimm EB. 25-hydroxyvitamin $\mathrm{D}$ and risk of myocardial infarction in men: a prospective study. Arch Intern Med 2008; 168:1174-1180.

24. Wang TJ, Pencina MJ, Booth SL, Jacques PF, Ingelsson E, Lanier K, et al. Vitamin D deficiency and risk of cardiovascular disease. Circulation 2008; 117:503-511.

\section{Authors Contribution:}

DPR - Concept and design of study, manuscript preparation, laboratory work; RN - Review of literature, preparation of first draft of the study and critical revision of manuscript; PKM - Concept, analysis and interpretation, literature search; PKP - Review of the study, manuscript preparation.

Source of Support: Nil, Conflict of Interest: None declared. 